\title{
Multi-source energy networks for cargo Vessels
}

\author{
Sanjana Ahmed, Alberto Castellazzi, Arthur Williams \\ Electrical and Electronic Engineering \\ University of Nottingham \\ Nottingham, UK \\ Eexsa70@nottingham.ac.uk
}

\begin{abstract}
The paper discusses the feasibility of installing renewable energy generation technologies on sea-going transport, taking into account the additional weight and power consumption. This study in based on the power management of a 26,198 tonne commercial chemical tanker. The management system would aim at reducing the number of generators as well as the power required from burning fossil fuels. After a process of elimination of potential technologies based on feasibility of the project and shipboard application, the work is focused towards photovoltaic and wind energy generation in combination with fossil fueled engines and Li-ion battery storage covering the higher energy density needs, and the intermittent nature of renewables. The network architecture is optimized in order to have the highest efficiency, and reduced system weight. The results show that successful management of the system can lead to reduction in generator requirement, and energy despite the weight of extra installations of photovoltaic and wind energy generation systems. By reducing the number of generators and allowing each remaining one to operate near their maximum power, the specific fuel consumption is improved, the efficiency is increased, resulting in significant fuel and cost saving, along with the mass of fuel to be carried on-board.
\end{abstract}

Keywords—ship, energy management, renewable energy, solar, marine, storage

\section{INTRODUCTION}

With an annual growth of $3.3 \%$ in world fleet, the international shipping industry contributes 3\% to global Green House Gas (GHG) emissions, and a staggering $85 \%$ of global demand for transport [1]. Measures are therefore being taken to reduce emissions such as $\mathrm{CO}_{2}, \mathrm{NO}_{\mathrm{X}}$, and $\mathrm{SO}_{\mathrm{X}}$ etc. (MARPOL Annex $\mathrm{VI}$ ), which defines specific limits per $\mathrm{g} / \mathrm{kWh}$ for all diesel engine types. The current total fuel oil consumption by ships amount to an excess of 350 million tonnes per annum, with the cost taking up to $50-60 \%$ of total operating cost of individual ships [2]. With newer regulations on emission from marine transport coming into effect in certain parts of the world, the feasibility of harvesting renewable energy on-board marine vessels need to be carefully considered. Due to the portable

TABLE 1: PHYSICAL AND ELECTRICAL SPECIFICATIONS OF

\begin{tabular}{|c|c|c|c|}
\hline \multicolumn{4}{|c|}{ TANKER } \\
\hline Length $(\mathrm{m}) \mathrm{x}$ & (m) & 159.0 & 27.1 \\
\hline \multicolumn{2}{|c|}{ Maximum Auxiliary Demand (kW) } & \multicolumn{2}{|c|}{1453} \\
\hline Generator & No. & $\begin{array}{l}\text { Prime Mover } \\
(\mathrm{kW})\end{array}$ & Output (kW) \\
\hline Main Generator & 3 & 660 & 600 \\
\hline
\end{tabular}

nature of the application, the additional weight penalty of renewable system installation, and thereby the extra energy expended, needs to be carefully studied and work is to be done in order to cover the gap between generation/storage technologies applied on-shore, against those that are suitable for portability and operate off-shore. This study will investigate the feasibility of powering the ship auxiliary systems of a commercial tanker whose specifications are given in Table 1 [3]. The auxiliaries may include pumps, blowers, coolers, compressors, vent fans, boilers, thrusters, hotel loads etc. A range of renewable energy technologies including wind and solar energy is considered to assess their suitability for maritime applications. Harvesting energy from motion of the vessel due to wave energy has been considered but the power generated is deemed too small, from the mechanical devices that have been tested [4], and there has been no optimal technology for converting the kinetic energy from ship motions to electric energy yet. The intermittency of renewable energy sources, and their variability due to voyage routes, demands that multiple inter-dependent sources be employed as ship powering options. Calculations are made on solar and wind power profiles for representative days and locations, to be compared with the vessel's power profile. The results are used to find the best possible mix of energy storage and generation, with an aim to keep the cost and weight at a minimum. The unpredictable nature of energy generation from renewable sources calls for its combined operation with Energy Storage Systems (ESS) in order to optimally manage power from each unit. With the load demand, from e.g. maneuvering systems, auxiliary machinery, air conditioning etc. of tankers being more or less constant, spikes of instantaneous power demands are rare, and therefore the high energy density, slow discharging batteries will be considered for the system, with supercapacitor being a good supplement for transients.

In the rest of the paper, section II describes the different energy generation methods employed onboard the vessel supplementary to its existing diesel engines, and possible architectures of integrating them into the ship grid. Section III outlines the sizing of and energy capacities of each of the installed energy sources and storage systems based on the space constraints of the vessel. Section IV calculates the extra weight related consumption of the installed system and comments on its feasibility. Section $\mathrm{V}$ outlines the management of the overall 


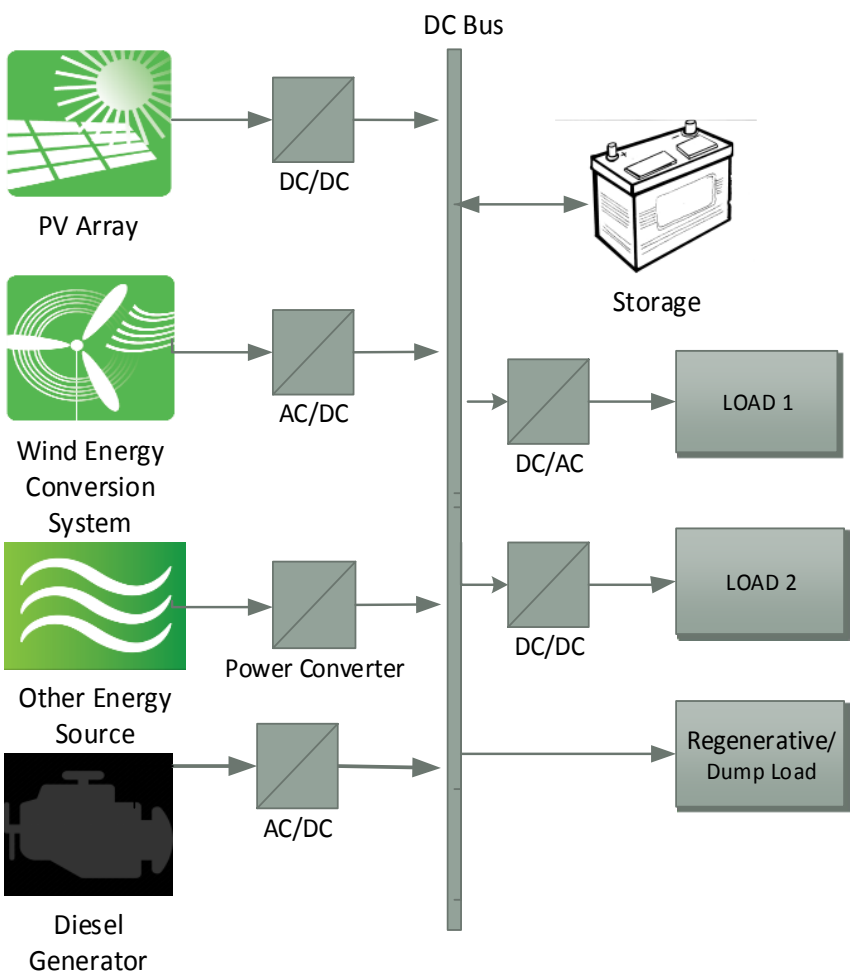

Figure 1a: Block diagram of potential multi-source renewable energy ship powering network with DC grid

system along with a control strategy to finally tie all the generation and storage devices in an effective arrangement.

\section{ENERGY GENERATION METHODS}

According to an amended report by DNV for Shipping 2020 [5], the uptake of hybrid systems in ship powering has been more rapid with batteries being placed in conjunction with fossil fueled engines resulting into a complex and efficient system of fuel mixture. The on-board integration of Distributed Generation (DG) such as PV systems, storage devices, and modern electronic loads, which are inherently DC, and the recent innovations in power electronics have created a drive towards replacing the traditional AC grid of commercial ships with their DC counterparts. The aim is to achieve higher efficiency through the reduction of conversion stages in incorporating the grid with DC sources and devices, lower emissions due to the higher efficiency system, attain more flexibility due to absence of AC switchboard and hence space utilization, and reduce weight, although with added complexity. Fig. 1 shows two alternative proposals for electrical power system architecture for the ship in relation to the energy storage system, as opposed to the conventional AC distribution. Fig. 1(a) contains a $1000 \mathrm{~V} \mathrm{DC}$ bus, which can be stepped down to lower voltages. It is suitable for avoiding reactive power in high power levels and operating prime movers at optimal speed without the need for synchronization based on bus frequency, resulting in fuel savings. The need for bulky transformers are eliminated. Further space and weight saving due to the flexible arrangement of DC bus system has been reported in [6] and [7].

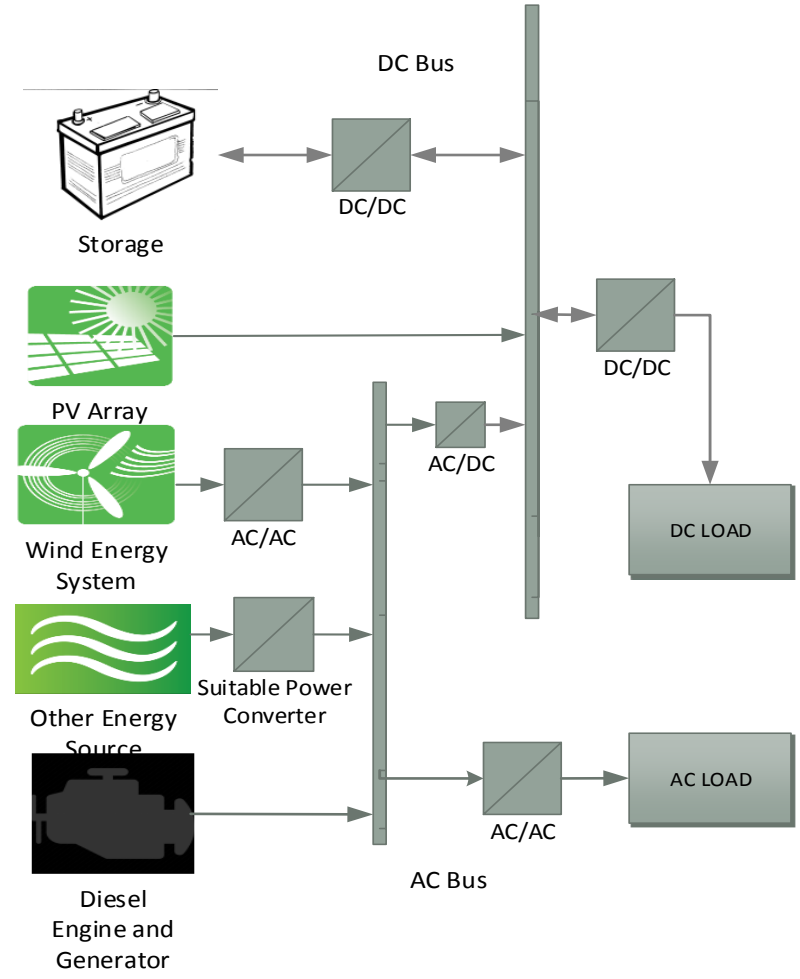

Figure 1b: Block diagram of alternative potential multi-source renewable energy ship powering network with parallel AC and DC grid

Fig. 1(b) incorporates a parallel AC/DC bus approach, with the $\mathrm{AC}$ bus at $690 \mathrm{~V}, 60 \mathrm{~Hz}$ following conventional ship power systems. Further levels of $440 \mathrm{~V}$ and $220 \mathrm{~V}$ can be derived through transformers form the main AC bus. Each of the AC generators and loads are connected to the $\mathrm{AC}$ bus while the $\mathrm{DC}$ sources and loads are connected via converters to the DC bus. A few studies which have merged the two distribution technologies together for shipboard propulsion in order to further reduce conversion stages have come up with the conclusion that parallel AC-DC bus increases efficiency and reduces weight and volume of power converter equipment but increases that of cabling due to the installation of separate AC and DC busses instead of one [8]. Maintenance and labor cost would also increase due to the presence of two different systems. The management strategy is to be optimized in various ways including number of inverters and hence their combined efficiency, voltage of bus, and therefore the appropriate wiring and safety measures, weight and volume.

The fastest developing green technology, namely solar power, will be investigated in more detail to meet ship auxiliary demand. A few projects have successfully integrated photovoltaics into ship power system with results of emission reduction, where some system configurations contribute to auxiliaries alone and others assist towards propulsion [9] [10] [11]. Different modes of operation of the PV arrangement can be addressed to identify the best possible network architecture when combined with the ship grid or operating stand-alone. 
TABLE 2: COMPARISON OF BATTERY TECHNOLOGY

\begin{tabular}{|c|c|c|c|c|}
\hline $\begin{array}{c}\text { Electro- } \\
\text { chemistry }\end{array}$ & $\begin{array}{c}\text { Life } \\
\text { (years) }\end{array}$ & $\begin{array}{c}\text { Monthly } \\
\text { self-discharge } \\
\text { at r.t.p. (\%) }\end{array}$ & $\begin{array}{c}\text { Energy } \\
\text { Density } \\
(\mathrm{Wh} / \mathrm{kg})\end{array}$ & $\begin{array}{c}\text { Cycle } \\
\text { Efficiency } \\
(\%)\end{array}$ \\
\hline Pb -acid & $5-8$ & $3-5$ & 40 & $63-90$ \\
\hline Li-ion & $8-10$ & $5-10$ & $80-190$ & 97 \\
\hline Na & 15 & $\sim 0$ & 100 & $89-92$ \\
\hline Ni-Cd & $10-15$ & $20-30$ & 50 & $72-78$ \\
\hline Ni-M-H & $8-10$ & $20-30$ & 80 & 66 \\
\hline Flow Battery & $>20$ & $\sim 0$ & $40-70$ & $75-85$ \\
\hline
\end{tabular}

Wind turbines mounted on ships require adequate differential wind speed over the turbine rotors and the design of turbine blades may need some alterations to optimize ship performance in presence of energy from wind sources [12]. It is however possible to carry out initial estimation using the data and characteristics of available Horizontal Axis Wind Turbine (HAWT) in the market, along with the meteorological wind speed data. The conclusions drawn in this study has utilized specifications of a market available HAWT. It can be considered that during times of high wind speed or facing a headwind which significantly increases the coefficient of drag $\mathrm{C}_{\mathrm{D}}$, the turbines can be folded down to avoid large backward drag force. In [13], Bockmann has proposed an optimized blade design for turbines installed on-board ships to maximize the net forward force of ships. Although the optimization is based on propulsion, it is also claimed to produce higher power than traditional wind turbines when the ship sails at half the wind speed, due to being designed for higher apparent wind speeds. This paper focuses on the power generation of the wind turbines as opposed to propulsion.

For storage, Li-ion battery technologies are chosen due to their high energy-to-weight ratio and their ability to undergo intensive charge and discharge cycles. Table 2 compares the longevity, energy-density, and efficiency of different battery technology to highlight the best possible option [14] [15] [16] [17]. It has also been noted that Li-ion batteries have a learning curve with a gradient of $21 \%$ which means their cost have fallen by $21 \%$ for every doubling of production. Due to their use outside grid, e.g. in electric vehicles and consumer items such as cell phones, the cost reduction for this technology of batteries has been faster and most prevalent hence likely to have further cost reductions in the future [18].

The network architecture and their integration into shipboard power system to supply an emission free powering option for the auxiliaries will be approached from a management perspective, since hybridization makes management more complex and diverse. Detailed energy management will be established through analyzing demand and availability of resources and imposing decision making algorithms on the operation scenarios of the network.
TABLE 3: SIZING OPTIONS OF PV ARRAY

\begin{tabular}{|l|c|c|}
\hline \multicolumn{2}{|c|}{ Modules per string } & Number of strings \\
\hline Minimum & 18 & 118 \\
\hline Maximum & 25 & 85 \\
\hline
\end{tabular}

\section{SIZING THE NEW SYSTEM}

The first stage of design involves the calculation of solar radiation data for the chosen area in order to be able to specify PV parameters. A fixed mounting is employed since adjustable or tracking types require mechanical bearings and design which would be complicated and costly. For calculating solar radiation on the panel, a solar constant value of $1367 \mathrm{~W} / \mathrm{m}^{2}$ is used, and the Clear Sky Index and Surface Albedo (Ground Reflectivity) values of the North Sea are taken from the NASA website using the appropriate Latitude and Longitude of $56^{\circ} \mathrm{N}$ and $3^{\circ} \mathrm{E}$ respectively [19].

For the photovoltaic system, the capacity of PV installation is limited by the useable area of the ship while the power output is dependent on solar insolation at that particular location [20]. Assuming 50\% space availability for solar panel installations, due to the shape of the ship not being rectangular and avoiding areas near the shade of cranes, flagstaff, and radar dome etc., an approximate top surface area of $2155 \mathrm{~m}^{2}$ can be utilized. Marine grade solar panels available in the market have been considered, narrowing on the standard 135 Watt module having an area of $1.01 \mathrm{~m}^{2}$ with each panel weighing about $10 \mathrm{~kg}$. It is thereby calculated that approximately 23 tonnes of panels can be accommodated on-board. Considering 5 hours of peak average daily sunlight, the panels could produce up to $1438 \mathrm{kWh} /$ day of energy. This can replace about $11 \%$ of auxiliary energy delivered by one $600 \mathrm{~kW}$ generator over a day.

The PV array is designed based on the known number of PV modules, with the minimum string length being enough to provide the required voltage to turn inverter $\mathrm{ON}$ and the maximum number providing lower voltage than maximum inverter input voltage. The following equations are used to determine the maximum and minimum number of modules for the array.

$$
\begin{gathered}
\text { Maximum number of modules per string }=\frac{V_{H I}}{V_{H M}} \\
V_{H M}=V_{O C}+V_{\text {inc }} \\
V_{\text {inc }}=-T_{L} \times \text { Temperature coefficient of } V_{O C}
\end{gathered}
$$

TABLE 4: PV AND WIND ENERGY CONVERSION SYSTEM PARAMETERS

\begin{tabular}{|c|c|}
\hline $\begin{array}{c}\text { Area Available for Solar Panel } \\
\text { Installation } \mathbf{( m}^{\mathbf{2}} \text { ) }\end{array}$ & 2155 \\
\hline No. of Panels & 2130 \\
\hline $\begin{array}{c}\text { Energy provided by PV over a day } \\
\text { (MWh) }\end{array}$ & 1.438 \\
\hline Wind Turbine Rated Power (kW) & 85 \\
\hline No. of Turbines & 8 \\
\hline Total Peak Power Provided (kW) & 73 \\
\hline $\begin{array}{c}\text { Combined weight of PV and Wind } \\
\text { Installations (tonnes) }\end{array}$ & 730 \\
\hline
\end{tabular}


Where, $\mathrm{V}_{\mathrm{HI}}=$ maximum acceptable inverter voltage which can be found from inverter specifications, $\mathrm{V}_{\mathrm{HM}}$ is the highest voltage expected from each module, $\mathrm{T}_{\mathrm{L}}$ is the difference of lowest ambient temperature from STC, and the open-circuit voltage, $\mathrm{V}_{\mathrm{OC}}$ at STC and its temperature coefficient is obtained from the specification of the solar panel used.

$$
\begin{gathered}
\text { Minimum number of modules per string }=\frac{V_{L I}}{V_{L M}} \\
\qquad V_{L M}=V_{M P}+V_{d e c} \\
V_{D e c}=T_{H} \times \text { Temperature coefficient of } V_{O C}
\end{gathered}
$$

Where, $\mathrm{V}_{\mathrm{LI}}=$ minimum acceptable inverter voltage, $\mathrm{V}_{\mathrm{LM}}$ is the lowest voltage expected from each module, $\mathrm{T}_{\mathrm{H}}=$ difference of highest ambient temperature from STC, and the voltage of the module at maximum power, $\mathrm{V}_{\mathrm{MP}}$ at $\mathrm{STC}$ is obtained from the specification of the solar panel used.

The array is finally designed with maximum allowed modules in series to allow lower current flowing for the same watts. Table 3 shows two extreme options for the series-parallel arrangement of PV modules. A series of 25 PV modules in 85 parallel strings thereby make up the array of 2125 modules onboard the tanker.

Wind speed data in three hour intervals for is collected from an offshore location in the North Sea, using NASA online resource. Unlike solar irradiation, wind cannot be predicted to have certain trend depending on the time of the day or the day of the year. When wind speed changes by a factor of 1 , the power generated changes by a factor of three. The mechanical power in the upstream wind entering the wind turbine blades is given by (7), and the output power of the turbine extracted by the rotor is given by (8), where $\rho$ is the air density in $\mathrm{kg} / \mathrm{m}^{3}$ and $\mathrm{A}$ is the swept area of the rotor blades in $\mathrm{m}^{2}$.

$$
\begin{gathered}
\text { Power }=1 / 2 \rho A v^{3} \\
\text { Power }=1 / 2 C_{P} \rho A v^{3}
\end{gathered}
$$

The difference in the equations is due to the Coefficient of Performance $\left(\mathrm{C}_{\mathrm{P}}\right)$ of the turbine which is essentially the fraction of upstream wind power that is extracted by the rotor, while the remaining energy passes into the downstream wind. This maximum limit of $59.3 \%$ energy which can be extracted from the mechanical energy of the upstream wind flowing through the turbine is given as the Betz's limit, although practical wind turbines achieve less than this value due to mechanical losses and aerodynamics. For slow-speed three-blade Horizontal Axis Wind Turbine (HAWT), $C_{P}$ is in the range of 0.2 to 0.4 [21]. A constant value of 0.3 is therefore chosen for the calculations for the wind speeds giving the wind power and energy output of the turbines.

Eight $85 \mathrm{~kW}$ wind turbines are required to replace the peak power provided by one more $660 \mathrm{~kW}$ generator and would incur a further 50 ton to be added to the total weight of the ship. However, the excess energy requirement due to overcoming the drag force on a generic wind turbine system can significantly add to the value, unless specifically designed for ship-board application, which will be looked into detail at a later stage. The data for solar and wind energy system is summarized in Table 4.

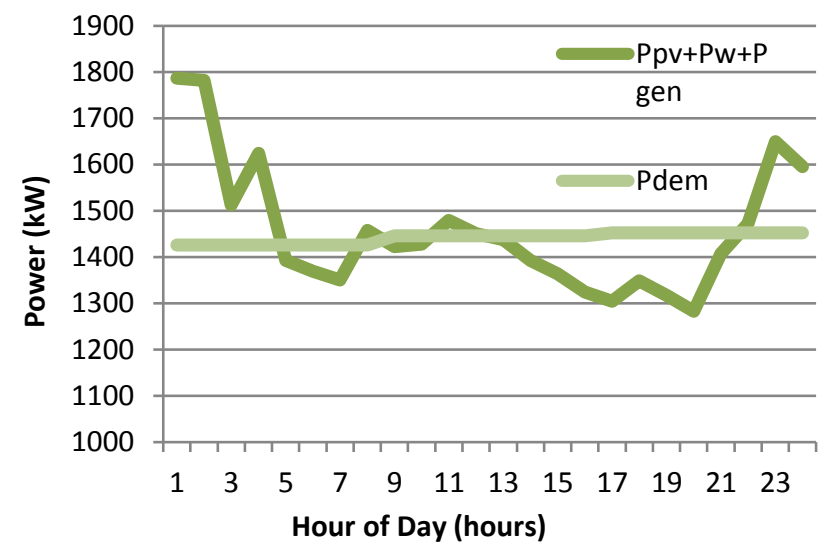

Figure 1: Generation and load profile for tanker operation during cargo unloading at port

The battery capacity must be determined from the maximum power deficit of the combined generation units in relation to load, which needs to be stored during generation for supplying at later times. It is therefore given by (9), where, $P_{\text {Gen }}$ is the power supplied by the Diesel Generator Set, $\mathrm{P}_{\mathrm{PV}}$ is the power generated by the PV Energy Conversion system, $\mathrm{P}_{\mathrm{W}}$ is the power given by the wind energy conversion system, $\mathrm{P}_{\mathrm{dem}}$ is the power demanded by the ship.

$$
\begin{gathered}
P_{\text {net }}=P_{G e n}+P_{P V}+P_{\mathrm{w}}-P_{d e m} \\
P_{\text {Tот } A L}=P_{G e n}+P_{P V}+P_{\mathrm{w}}+P_{\text {Batt }}
\end{gathered}
$$

Each generator will come into use only when $\mathrm{P}_{\text {TотAL, }}$ i.e. the combination of the renewable sources and stored energy, and the previous generator, is unable to supply load demand. Fig. 2 shows the load profile of the tanker under the condition of cargo handling at port, when demand is at a maximum. Without renewable energy systems, all three diesel generators would be running to meet the load demand, giving an output power of $1,800 \mathrm{~kW}$. However with the help of wind and PV generated power, and that drawn from the battery during the deficit hours, it would be sufficient for the tanker to operate with only 2 diesel generators for auxiliary electrification, in place of 3 .

From Fig. 2, the energy deficit during the 14th to 22nd hour of the day is highest and the battery can be sized according to this requirement calculated to be approximately $867.7 \mathrm{kWh}$. Considering 3 days of autonomy and $50 \%$ depth of discharge, the required battery capacity is calculated to be, 5.21 MWh. With $12 \mathrm{~V}$ battery cells available in the market, the combination of 2066 batteries of 210 Ah rating will be able to supply the demand. As a rule of thumb, the battery pack will be able to take as input $\mathrm{C} / 5$ or $1 \mathrm{~kW}$, where $\mathrm{C}$ is the Battery capacity in Wh. The largest power peak during excess generation is $360 \mathrm{~kW}$; therefore no further energy storage device is required to absorb this power. The average weight of $210 \mathrm{Ah}$ batteries can be taken as $61 \mathrm{~kg}$ each, giving an equivalent total of 126 tonnes for the storage system, and volume equal to that of one 30 foot container.

The combined generation and storage system therefore total approximately 200 tonnes. When compared with a case study of an A-Type container ship [22], it is seen that Waste Heat 


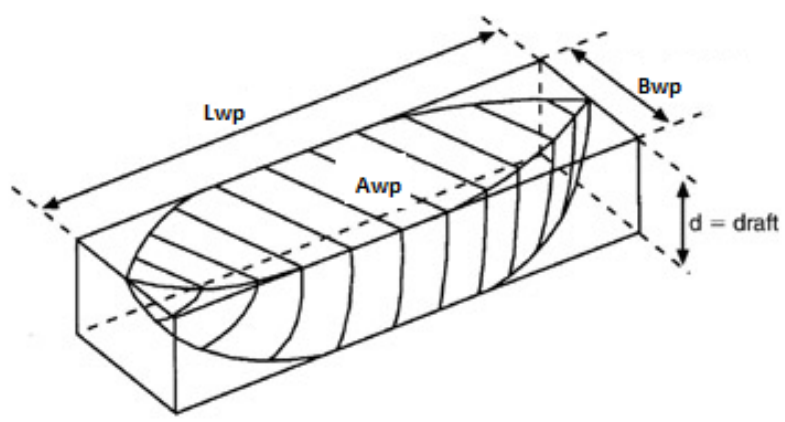

Figure 3: Ship dimension used for calculation of resistance acting upon ship

Recovery (WHR) and Exhaust Gas Recirculation (EGR) systems, when retrofitted into ships to meet current regulations, can have weight penalty of up to 900 tons, which is far greater than installation of the renewables.

\section{A. Extra Weight Related Consumption}

A method is detailed for the estimation of extra energy input required to propel the ship owing to the additional resistance imposed by the weight of the new renewable energy system. The extra weight $w$ incorporates the weight of the wind turbine system, solar panels and auxiliaries and battery storage system, less the weight of the third generator which is now redundant. Resistance which acts upon the ship comprises of three main divisions, namely the Frictional or Skin Resistance $\left(\mathrm{R}_{\mathrm{f}}\right)$, Wave Resistance $\left(R_{w}\right)$ and Air Resistance $\left(R_{a}\right)$ [23]. $R_{f}$ is the resistance due to the viscous stresses that the water exerts on the hull of the ship, $R_{w}$ is caused by waves generated by the motion of the ship and $R_{a}$ is resistance caused by the flow of air over the ship. There will be a slight reduction in $\mathrm{R}_{\mathrm{a}}$ due to the amount of the hull that dips down into water; however this quantity is very small, about $2 \%$, and therefore can be ignored [24]. The $R_{w}$ is also more heavily dependent on the hull shape and speed of ship, over displacement, and therefore will not be looked into detail in this study considering the hull shape and speed remains constant for both scenarios [25]. For $\mathrm{R}_{\mathrm{f}}$, using the specified Tonnes per Inch (TPI) of the tanker, it is possible to find the increase in the draught of the ship, given by $d$, and thereby the surface area of the ship pushing through water [26].

$$
\begin{gathered}
d=\frac{w}{T P I} \\
T P I=\frac{\text { Weight to increase the draught one inch }(L T)}{1 \text { in }} \\
\text { Or, } T P I=\frac{A_{w p}}{420}\left(\frac{L T}{i n}\right)
\end{gathered}
$$

Where $\mathrm{A}_{\mathrm{wp}}$ is the water plane area in $\mathrm{ft}^{2}$, and is expressed by the following equation, in which, $\mathrm{L}_{\mathrm{wp}}$ is the length of the water plane, $B_{w p}$ is the hull's largest beam on water plane and $C_{w p}$ is the water plane area coefficient, which is given as 0.95 for a typical tanker at an approximate cruise speed of 17 knots [24].

$$
A_{w p}=C_{w p} \times L_{w p} \times B_{w p}
$$

Putting the values in place, with $\mathrm{L}_{\mathrm{wp}}$ of $147 \mathrm{~m}$ or $482 \mathrm{ft}$ and the previous value for beam results in water plane area of $40590 \mathrm{ft}^{2}$, TPI of $97.63 \mathrm{LT} /$ in and $\mathrm{d}=2.07$ inch. After conversions into

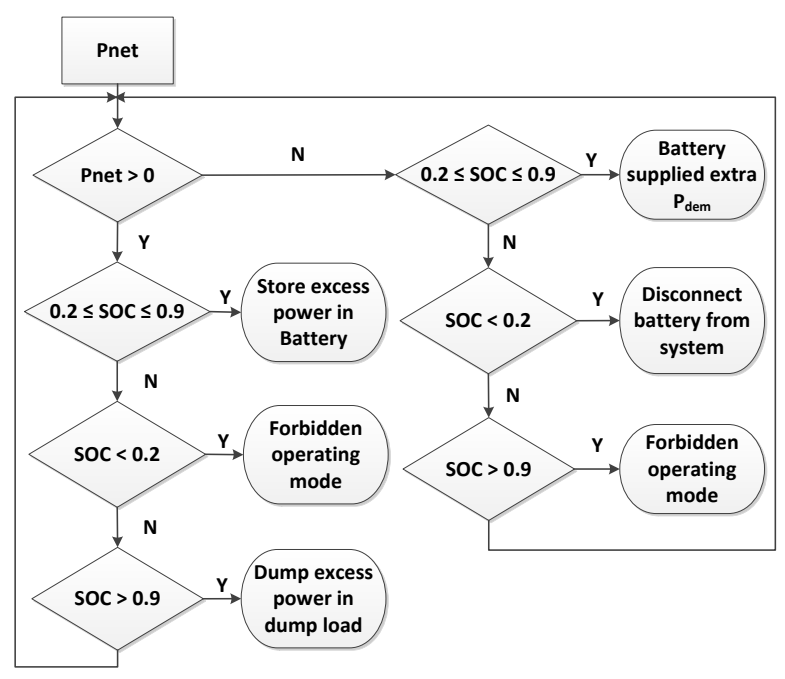

Figure 4: Flow chart of power flow management system

suitable units, this gives an increment of $7.96 \mathrm{~m}^{2}$ in wetted surface area $\left(A_{s}\right)$, giving rise to higher $R_{f}$, which in turn will result in greater fuel consumption for propulsion, given the speed $\mathrm{V}$ of the ship remains constant.

$$
R_{f}=1 / 2 \rho V^{2} A_{s} \times C_{f}
$$

Where $C_{f}$ is specific frictional resistance coefficient and $R_{n}$ is the dimensionless Reynold's number, given by the following equations [20] [25]. The kinematic viscosity of fluid, given by $\mathrm{v}$, varies according to temperature for a specific fluid. At an average $10^{\circ} \mathrm{C}$, the kinematic viscosity of water is given as 1.307 $\mathrm{x} 10-6 \mathrm{~m}^{2} / \mathrm{s}$ [27].

$$
\begin{aligned}
C_{f} & =\frac{0.075}{\left(\log R_{n}-2\right)^{2}} \\
R_{n} & =\frac{V L_{w l}}{v} \\
P_{e x} & =R_{f} \times V
\end{aligned}
$$

The resulting $\mathrm{R}_{\mathrm{f}}$ is $467.3 \mathrm{~N}$, which when multiplied by the speed of the ship gives the increase in effective towing power, Pex, as $4089 \mathrm{~W}$. Over a day, this equates to an added energy consumption of $98 \mathrm{kWh}$, which is much less in comparison to the extra $6155 \mathrm{kWh}$ of energy given by the combined renewable energy system.

\section{MANAGEMENT}

With multiple energy sources such as diesel engine, fuel cells, solar and wind turbines integrated into providing shipboard power, the presence of ESS allows reliability and redundancy by collective usage and management of the sources. A power management strategy has been developed to control the power flow in the hybrid system, and different modes of operation are assigned depending on the different generation and load conditions, as well as the state of the storage system. It is to be noted that when batteries are used as storage devices, their lifetime are sharply affected by their Depth of Discharge (DOD), i.e. there is only a certain range within which a battery can safely 
charge and discharge while keeping a healthy lifetime. This range is given between $20 \%$ to $90 \%$ of the instantaneous state of charge (SOC) of a Lithium-ion battery, which is used in this design [28]. A flow chart of the management system is based on the instantaneous SOC of the battery and Pnet at each instance, which are the two input and control variables to the system giving rise to six different modes of network operation, as shown in Fig. 4, and as described below.

1) Mode 1: When the sum of instantaneous power generated by renewable technologies is greater than the load which is unmet by the generator $\left(\mathrm{P}_{\text {net }}>0\right)$, and the SOC of the battery is within permissible range, the excess energy is stored in the battery for later use.

2) Mode 2: The second mode is similar to the first where there is excess power in the network but the battery SOC is lower than the permitted limit of $20 \%$, hence this operating mode must be forbidden.

3) Mode 3: When there is surplus energy from renewables combined with a battery SOC which is higher than the upper limit, the excess power should be dumped through a load in order to avoid overcharging of batteries.

4) Mode 4: On the other hand, when load demand is greater than generation by renewables and generators, the battery storage system must provide the extra requirement, given the battery SOC is within permitted range to discharge.

5) Mode 5: During discharge of battery, if the SOC falls below its permitted lower limit of $20 \%$, the storage system must be disconnected from load to prevent battery over-discharge. At this point, offline generators must come into operation to provide the load demand.

6) Mode 6: Similarly if demand is greater than generation but SOC of battery is higher than $90 \%$, the system is in a forbidden operating mode again.

The entire process can be controlled through a set of switches, logic gates and control signals. The system thus alternates between modes $1,3,4$, and 5 . It operates at mode- 1 to store excess power in the network in the battery until mode 3 is detected whereby the battery power becomes zero and the excess power is dissipated by dump load. When the system operates at mode 4 , the battery discharges to provide the loads until it reaches its lower threshold value and the system moves into mode 5 in which diesel generators come online to retain the loads.

\section{CONCLUSION}

Calculations show that the large available area of the commercial vessel allows it to have substantial PV installations and thereby meet a high percentage of energy generation through PV. Although wind turbines require further investigation based on backward drag force, initial calculations are based on existing HAWT turbines which provides significant amount of renewable energy. The additional weight of the installations is also within reasonable limits to encourage potential investments in this less ventured for area. With multiple energy sources such as diesel engine, fuel cells, solar and wind turbines integrated into providing shipboard power, the presence of ESS allows attainment of efficiency and redundancy by collective usage and management of the sources. The reduction of one auxiliary generator in the chemical tanker studied in this paper allows the remaining generators to operate near their maximum power, allowing better Specific Fuel Consumption (SFC), and increased efficiency, which can result in significant fuel and cost saving, along with the mass of fuel to be carried on-board.

\section{REFERENCES}

[1] DNV, "Shipping 2020," Det Norse Veritas As, Hovik, 2012.

[2] Royal Academy of Engineering, "Future Ship Powering Options: Exploring ALternative Metohds of Ship Propulsion," Royal Academy of Engineering, London, 2013

[3] Marine Traffic, "Marine Traffic," Tokyo Marine, 2 April 2015. [Online]. Available:

http://www.marinetraffic.com/ais/details/ships/shipid:713221/mmsi:538 004002/imo:9490301/vessel:FUJI_GALAXY. [Accessed 2 April 2015].

[4] Yu-Jen Wang, "Harvesting energy from ship rolling using an eccentric disk revolving in a hula-hoop motion," 2014 International Power Electronics Conference (IPEC-Hiroshima 2014 - ECCE ASIA), Hiroshima, 2014, pp. 1420-1424.

[5] Det Norske Veritas AS, "Shipping 2020," Det Norske Veritas AS, Norway, 2012.

[6] J.F. Hansen, J.O. Lindtjørn, K. Vanska, "Onboard DC Grid for enhanced DP operation in ships," in Dynamic Positioning Conference, Houston, 2011.

[7] B. Zahedi and L. E. Norum, "Modeling and Simulation of All-Electric Ships With Low-Voltage DC Hybrid Power Systems," in IEEE Transactions on Power Electronics, vol. 28, no. 10, pp. 4525-4537, Oct. 2013.

[8] J. S. Chalfant, C. Chryssostomidis1 and M. . G. Angle, "Study of Parallel $\mathrm{AC}$ and DC Electrical Distribution in the All-Electric Ship," in Grand Challenges in Modeling and Simulation (GCMS10), Ottawa, 2010.

[9] Kyoung-Jun Lee, Dong-Sul Shin, Jong-Pil Lee, Dong-Wook Yoo, HanKyu Choi and Hee-Je Kim, "Hybrid photovoltaic/diesel green ship operating in standalone and grid-connected mode in South Korea Experimental investigation," 2012 IEEE Vehicle Power and Propulsion

[10] , Seoul, 2012, pp. 580-583.

[11] X. J. Tang, T. Wang, C. Zhi and Y. M. Huang, "The design of power management system for solar ship," Transportation Information and Safety (ICTIS), 2015 International Conference on, Wuhan, 2015, pp. 548553.

[12] S. S. Eirik Bøckmann, "Wind Turbine Propulsion of Ships," in Second International Symposium on Marine Propulsors, Hamburg, Germany, 2011.

[13] Nippon Yusen Kabushiki Kaisha, "World's First Solar-Power-Assisted Vessel Further Developed -Car Carrier Auriga Leader to be Fitted with Hybrid Power Supply System and Ballast-Water Management System, and Adapted to Use Low-Sulfur Fuel," 25 May 2011. [Online]. Available: http://www.nyk.com/english/release/1414/ne_110525.html. [Accessed 2 12 2015].

[14] E. Bøckmann, S. Steen, "Wind Turbine Propulsion of Ships," in Second International Symposium on Marine Propulsors, Hamburg, Germany, 2011.

[15] Z. Zhou, M. Benbouzid, J. F. Charpentier, F. Scuiller, T. Tang, "A review of energy storage technologies for marine current energy systems," Renewable and Sustainable Energy Reviews, vol. 18, pp. 390-400, Feb. 2013.

[16] X. Luo, J. Wang, M. Dooner, J. Clarke, "Overview of current development in electrical energy storage technologies and the application potential in power system operation", Applied Energy, Volume 137, 1 January 2015, Pages 511-536

[17] Z. F. Hussien, L.W. Cheung, F.M. Siam, A.B. Ismail, "Modeling of Sodium Sulfur Battery for Power System Applications," Elecktrika, vol 9, no. 2, pp. 66-72, 2007. 
[18] C. Ponce de León, A.F. Ferrer, J. González-García, D.A. Szanto, F. C. Walsh, "Redox flow cells for energy conversion," Journal of Power Sources, vol. 160, no. 1, pp. 716-732, 2006.

[19] M. Wilshire, "GLOBAL TRENDS IN CLEAN ENERGY," Bloomberg New Energy Finance, London, 2014.

[20] NASA Langley, "Surface meteorology and Solar Energy," POWER: Prediction of Worldwide Energy Resource Project, [Online]. Available: https://eosweb.larc.nasa.gov/sse/. [Accessed 12 2016].

[21] G. J. Tsekouras, F.D. Kanellos "Optimal Operation of Ship Electrical Power System with Energy Storage System and Photovoltaics: Analysis and Application," WSEAS TRANSACTIONS on POWER SYSTEMS, pp. 145-155, October 2013.

[22] M. R. Patel, Wind and Solar Power Systems: Design, Analysis and Operation, CRC Press, 2006

[23] B. Ø. Nielsen, 8500 TEU Container Ship Green Ship of the Future Concept study, Odense Steel Shipyard Ltd, 2009.

[24] D. G. M. Watson, Practical Ship Design, Gulf Professional Publishing, 2002.

[25] MAN Diesel \& Turbo, "Basic Principles of Ship Propulsion," MAN Diesel \& Turbo, Copenhagen, 2011.

[26] University of Strathclyde, "Basics of Ship Resistance," University of Strathclyde, Strathclyde, 2011.

[27] P.H. Miller, "Hull Form and Geometry: Intro to Ships and Naval Engineering (2.1)," United States Naval Academy, Annapolis, 1997.

[28] 26th ITTC Specialist Committee, "ITTC - Recommended Procedures Fresh Water and Seawater Properties," IITC, 2011.

[29] M. Stadler, M. Kloess, M. Groissböck, G. Cardoso, R. Sharma, M. C. Bozchalui and C. Marnay, "Electric Storage in California's Commercial Buildings," Applied Energy, vol. 104, pp. 711-722, 2013.

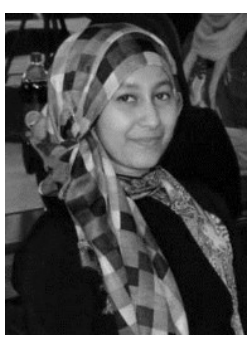

Sanjana Ahmed received the B.Sc. degree in electrical and electronic engineering from BRAC University, Dhaka, Bangladesh, in 2013 and the M.Sc. degree in electrical engineering for sustainable and renewable energy from University of Nottingham, Nottingham, UK, in 2014. She is currently pursuing the Ph.D. degree in electrical and electronic engineering at the

Power Electronics, Machines and Control Group at the University of Nottingham, UK.

Her research interest includes renewable energy technologies, management of power network, energy storage and marine application of renewable energy.

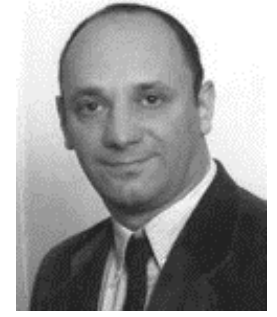

Alberto Castellazzi received the M.S. degree in physics from the University of Milan, Milan, Italy, and the Ph.D. degree in electrical engineering from the Munich University of Technology, Munich, Germany. He is currently a Lecturer in power electronics with the Power Electronics, Machines, and Control Group, University of Nottingham, Nottingham, U.K. He has been engaged in research in power electronics circuits and devices for more than ten years and has been affiliated to some of the main European institutions in the field (Siemens Corporate Technology, TU Munich, ETH Zurich, ALSTOM-PEARL). His current research interests include the multi-domain multilevel abstraction modeling and simulation of power components and assemblies, novel packaging and integration approaches for semiconductor power devices, high-temperature electronics $(\mathrm{SiC}), \mathrm{dc}-\mathrm{dc}$ converters, and reliability investigations.

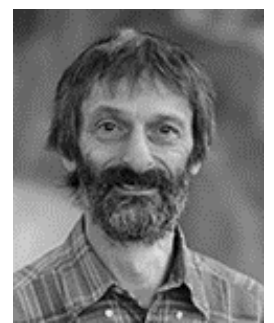

Arthur Williams received a B.A. in engineering science from St. John's College, Oxford and then worked for GEC Large Machines in Rugby in Electrical Machine Development. Later he began research into micro-hydro systems, often working in collaboration with the Intermediate Technology Development Group (now "Practical Action"). He completed a PhD at Nottingham Trent University in 1992. He has been involved in the development and dissemination of low-cost technologies for rural electrification, and has visited Nepal, Pakistan, Sri Lanka and Peru in connection with this work. He has been a lecturer in Electrical and in Mechanical Engineering at Nottingham Trent University before transferring to the University of Nottingham in 2007. He lectures in the field of sustainable energy and is course director for the interdisciplinary MSc in Sustainable Energy Engineering. His research is in Renewable Energy systems. 